\title{
A constant problem
}

\section{行き詰まる

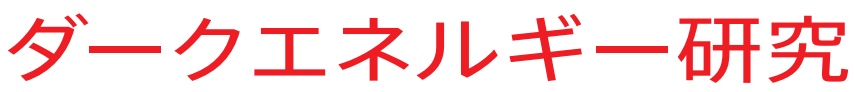

Nature Vol.448(245-248)/19 July 2007

10 年前の発見時には大歓迎されたダークエネルギーの研究が、ここにきて研 究者を失望させているのはなぜなのだろうか ? Geoff Brumfielが取材した。

1998 年、2つの天文学者のチームが、宇 宙は自分自身を引き伸ばしていると報告し た。これは衝撃的な報告だった。宇宙が膨 張していることは 1920 年代から知られて いたが、この膨張は減速しており、遠い将 来にはほぼ完全に止まるだろうと考えられ ていたからである。しかし、1990年代後 半に行われた遠方の超新星の観測は、膨 張はまったく減速しておらず、むしろ加速 していることを示唆していた。ジョンズホ プキンズ大学 (メリーランド州ボルティモア) の天文学者Charles Bennettは、「この発 見は信じられないほど直観に反していた。 私はそれを信じなかった」と振り返る。

しかし、数年のうちにBennettやこの 分野の研究者のほぼ全員が、それまでの 考えを改めざるを得なくなった。観測結果 は確実なものになっていったし、宇宙の膨 張が加速していることは理論の行き詰ま りを救うとみられたからである。Bennett のチームを含むさまざまな研究グループが ビッグバンの名残の電磁波を観測していた が、その結果は、宇宙の重力が宇宙を平 坦にしていることを示していた（平坦な宇 宙とは、宇宙の膨張速度とそれに含まれる 質量が均衡しており、膨張速度を減じな がら永遠に膨張を続けるが、ある一定の 大きさ以上にはならず、またけっして収縮 には転じないというもの)。しかし、ほか の観測結果は、それほど大きな重力効果 を及ぼすには、宇宙にある物質の量が少な すぎることを示していた。この不足分は、
まだ見つかっていないダークマターを考慮 に入れても埋めることはできなかった。

幸いにも、相対性理論では物質だけで なくエネルギーも重力効果をもつことにな る。そして、宇宙の膨張を加速するのに必 要なエネルギー量は、その重力により平坦 性問題を解決するのに必要なエネルギ一量 にかなり近いことがわかった。このエネル ギーはすぐに「ダークエネルギー」として 知られるようになった。シカゴ大学 (イリ ノイ州）の宇宙論研究者Michael Turner は、「ダークエネルギーは、宇宙の起源と 未来に関するすばらしい洞察を与えてく れるようにみえた。その正体さえ明らか になれば、すべてがうまくいくように思 われたのだ」と話す。

それから約10年が過ぎた今、研究者た ちは、1つの理論的な難問をより大きな難 問に置き換えてしまっただけのようにみえ る。その後の観測は、ダークエネルギーの 正体についてほとんど何も明らかにしてお らず、ダークエネルギーを説明する理論は 前進するための手がかりを欠いている。天 文学者たちは新しい観測装置を投入して、 やっとのことで歩を進めているが、こうし た観測により問題を解決できる保証はほ とんどない。もちろん、今後の観測にどれ だけカを入れるべきかについても、研究 者の意見は一致していない。ハーバード大 学の宇宙物理学者Avi Loebは、「問題は、 今後の観測からどれだけの情報を得られ るのかという点にある」と話す。 


\section{見えない謎}

大きな問題は、ダークエネルギー自体は目 に見えないということだ。ダークマターと 同じように、ダークエネルギーはその効果 を通じてのみその存在を知ることができ る。ダークエネルギーの場合は、宇宙の膨 張に及ぼす効果がそれに当たる。ダーク エネルギーと膨張の加速との関係は、「ダー クエネルギーの状態方程式」に現れるある 定数によって決まる。これは、ダークエネ ルギーが及ぼす圧力を単位体積当たりの ダークエネルギー量で割ったものである。

膨張が加速しているなら、状態方程式 の定数はマイナスでなければならない。そ して、状態方程式の定数が-1であれば、 ダークエネルギーが宇宙の不変の性質、つ まり宇宙定数 (宇宙項) であることになる。 宇宙定数はアインシュタインの一般相対性 理論に現れる定数である。皮肉にも、彼 は宇宙を同じ大きさにとどめるために宇宙 定数を導入した。アインシュタインは、宇 宙が実際には膨張しているという事実を 受け入れたとき、宇宙定数を自分の「生涯、 最大の過ち」とよんで方程式から取り除 いた。しかし、状態方程式の定数が-1で あるなら、ダークエネルギーは宇宙定数と しての条件を満たす。そして、最新の観測 結果によると、状態方程式の定数が-1で ある可能性はかなり高い。

スタンフォード大学（カリフォルニア州） の宇宙論研究者Leonard Susskindは、 「ダークエネルギーの状態方程式の定数が 本当に-1であるなら、その正体について

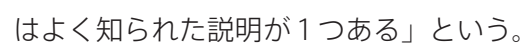
物理学者たちは数十年前から「真空の工 ネルギー」というものの存在を仮定してき た。これは、真空の中で生まれたり消え たりする量子的粒子からなる原始の泡で ある。この真空のエネルギーなら、観測さ れているような加速膨張の駆動力となる かもしれない。また、真空のエネルギーに よる加速は休みなく続くだろう。真空の エネルギーは空間にもともと備わった性質 であるため、「宇宙が膨張すると宇宙の真 空のエネルギーも増え、圧力とエネルギー 密度との比は変化せず、-1に固定される ことになる」とSusskindは説明する。

この説明には1つだけ理論的矛盾があ

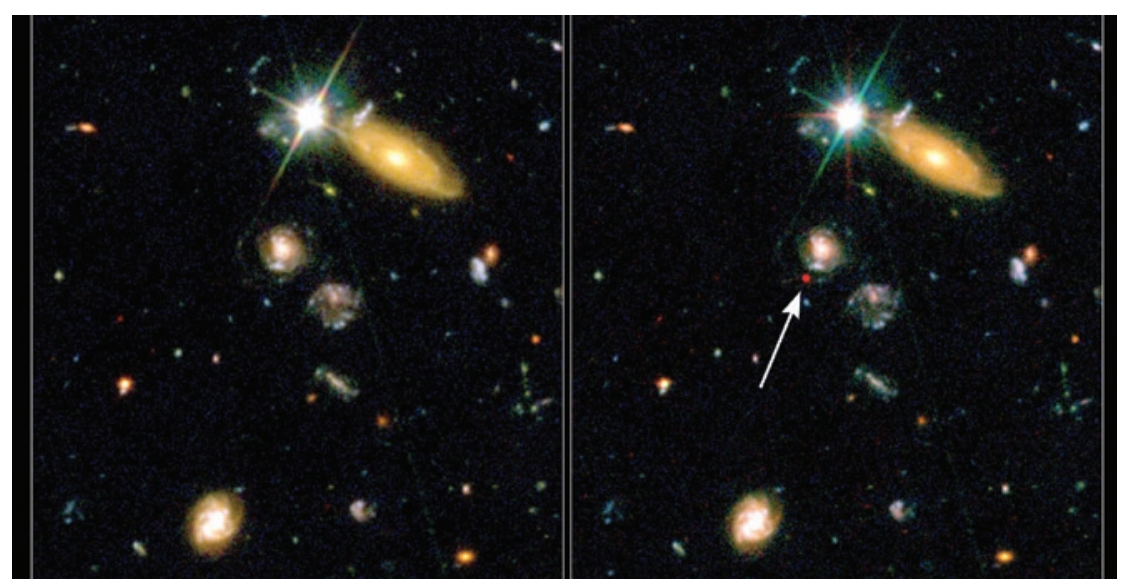

夜空の一部を連続して撮影した画像から、超新星爆発（右写真の赤い点）を見つけることができる。

る。天文学者が観測したダークエネルギー の効果は比較的弱いため、物理学者が計算 した真空のエネルギーは、この効果を説明 するのに必要な量の $10^{100}$ 倍以上の大きさ になってしまうのである。ダークエネルギー がこんなに大きかったら、私たちの宇宙は 一瞬にしてバラバラになってしまうだろう。 「どのように計算しても、真空のエネルギー は莫大な量になってしまう。自然に小さな 值をとらせる方法はない」とTurnerはい う。そのため物理学者の多くは、隠れた自 然の対称性による未知の効果が真空の工 ネルギーを打ち消しているのだろうと考え た。このような「そのうち消えてくれると いいのだが」という考え方は、物理学では 珍しいものではなく、場合によってはこれ が唯一の前進方法になることもある。とは いえ、真空のエネルギーについてこのよう な考え方をするのは「まったく愚かなこと だった」とSusskindは認めている。

「そして、私自身もそうした愚かな考え 方をしていたことを白状しなければならな い」と、彼はほとんど申し訳なさそうに話 す。今のSusskindは、このような考え方 はしておらず、この難問に対してある種の 解答を提案している。「多くの素粒子物理 学者に人気のある『ひも理論』では、私 たちが観測できる宇宙は、より大きな『多 元的宇宙』が含む $10^{500}$ 個の宇宙の $1 つ に$ すぎないと考えることができ、そう考える ことが望ましくさえある」と彼は語る。真 空のエネルギーは宇宙ごとに異なる值をも ち、多くの宇宙、ひょっとするとほとんど の宇宙では、実際に莫大な值になっている
のだろう。しかし、私たちの宇宙では小さ い值に違いない。なぜなら、私たちのよう な観測者が進化できるのは、真空のエネル ギーが小さい宇宙だけであるからだ。

この種の「人間原理」の議論は多くの科 学者をうんざりさせている。批判的な人久 は、この種の推論は検証することがほとん ど不可能であり、宇宙に関するより深い洞 察を与えてくれるものではないと指摘す る。プリンストン大学 (ニュージャージー州) の理論研究者Paul Steinhardtは、「人間 原理と無作為性は何も説明していない。大 部分の理論研究者がこうした議論を受け入 れていることに私は失望している」と話す。

問題は、これよりも有望そうにみえる ほかの説明がないことだ。一部の人々は、 問題はアインシュタインの重力理論にある と主張して、ダークエネルギーと合うよう にこれを修正しようとしている。「ダーク エネルギーが重力の一種であるとしたら、 それはとても幸運なことだ。物理学の根 本的な謎に挑むことができるのだから」と ニューヨーク大学のGeorgi Dvaliは話す。 しかし、彼らの修正にはほとんど意味が ないと考える人もいる。宇宙全体はとも かく、「そうした重力理論が、太陽系で矛 盾が生じないようにするのは容易なこと ではないからだ」とTurnerはいう。

ダークエネルギーは宇宙の時間の経過と ともに変化する性質なのではないかと考え る人もいる。ある人は、ダークエネルギー は宇宙規模の長距離で働く5番目の力（残 りの4つは、電磁気力と2つの核力と重力) なのではないかと考えている。またある人 
は、ビッグバンの直後に起きたとされてい るインフレーションの余波ではないかと考 えている。インフレーション期は、極端な 膨張が起きていた期間であった。その後の 宇宙の歴史を通じて、この現象が何らかの 尾を引いている可能性はないのだろうか?

提案されているさまざまな仮説は、概念 的には異なっているが、数学的には同等で ある。これらはいずれも、ダークエネルギー が時間とともに変化することと、状態方程 式の定数が-1に固定されないことを要請 する。「ダークエネルギーが変化すると考え れば、今日のダークエネルギーの小ささを 説明しやすくなるだろう」とSteinhardtは いう。さらに、ダークエネルギーの変化は、 この宇宙のほかの特徵にも影響を及ぼすか もしれない。例えば、基本定数と考えられ ている定数の一部に検出可能な影響を及ぼ すなら、それはこの仮説にとってプラスに なるだろう。しかし、批判的な人々は、よ ほどの事情がないかぎり、こうした考え方 が受け入れられることはないとみている。

\section{希望の光}

全体としては、この問題の理論的側面は うまくいっていない。カリフォルニアエ
科大学 (同州パサデナ) の理論物理学者 Sean Carroll は、「私たちはあらゆること を試してみたが、うまくいったものはな かった」という。「今必要なのは、もう少 しの手がかりだ」。

状態方程式の定数を精密に測定するた め、天文学者たちは新世代のダークエネル ギー探査機を計画している。彼らはすで に1a型超新星の詳細な観測を進めている。 ローレンスバークレー国立研究所（カリフォ ルニア州）の天文学者Saul Perlmutter は、超新星を使って宇宙の膨脹の加速を 測定する方法の原理を次のように説明す る。1 1 型超新星爆発は、連星系の大きな 星から小さな星へと物質が流れ込んだ結 果、小さな星の質量がしきい值を超え、大 規模な熱核反応により爆発することで起 こる。どの星も同じ質量しきい值で爆発す るため、1 1 型超新星はみな同じ量のエネ ルギーを出すことになり、その絶対的な明 るさ (等距離から見た明るさ) はどれも同 じになるはずだ。ならば、1a型超新星を 地球から見たときの相対的な明るさを比 較することにより、超新星までの距離を正 確に測定できることになる。この方法で超 新星までの距離を測定し、光の赤方偏移
を使ってその速度を測定することにより、 宇宙の膨張がどの程度加速されているか を知ることができる。Perlmutterらは今、 超新星の仕組みを詳細に解明し、計算結 果の精度を上げるために、観測数を増や そうと努力している (p.13写真参照)。

超新星は最もよく解明されている天体の 1つだが、宇宙の膨張の加速を測定する唯 一の方法ではなく、遠方の銀河団からのX 線を調べるという方法もある。スタンフォー ド大学のX線天文学者Steve Allenによる と、超新星の場合のように、銀河団の温度 と明るさには標準的な関係があるため、地 球から任意の距離にある銀河団が遠ざかる 速度を測定することができるという。

ダークエネルギーの効果は、より複雑な 方法によっても測定できる。銀河団や銀 河群の重力場は、重力の井戸に落ち込む 光の波長を青色方向に変化させ、井戸か ら出てくる光の波長を赤色方向に変化さ せる。ピッツバーグ大学 (ペンシルベニア 州）の天文学者Ryan Scrantonは、ビッ グバンの名残である宇宙マイクロ波背景 放射にこうした効果が現れるときにダー クエネルギーが影響を及ぼしているはず だと考えている。

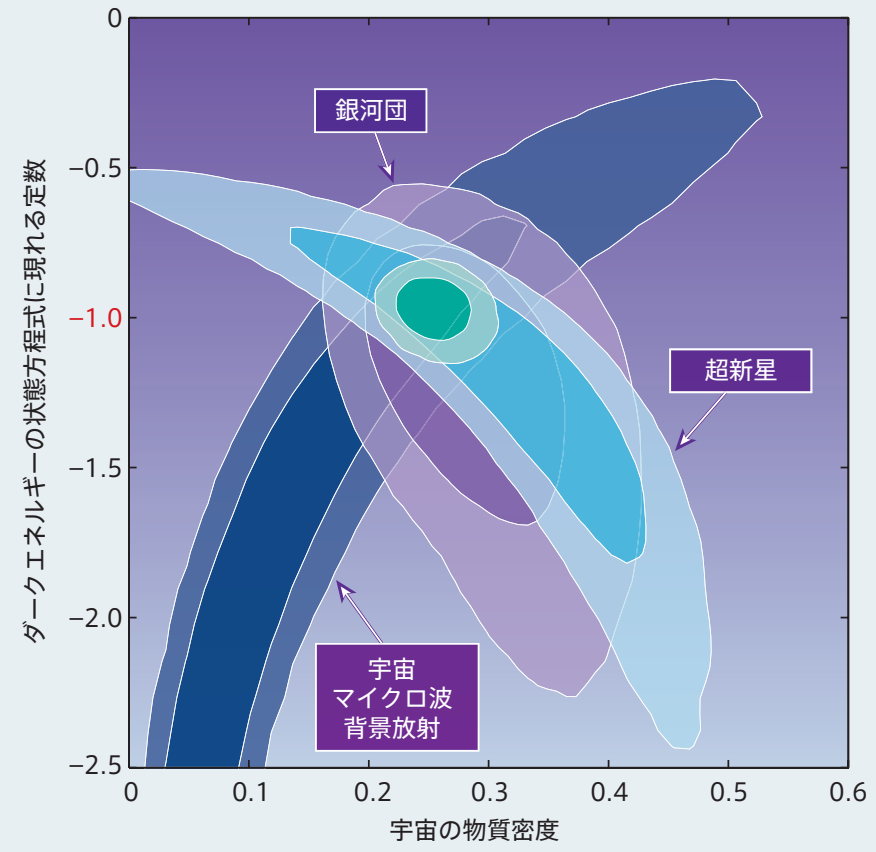

\section{ダークエネルギーを追い詰める}

さまざまな観測法を組み合わ せることで、宇宙の物質密度 とダークエネルギーの状態方 程式の定数がとり得る值を絞 り込むことができる。

宇宙マイクロ波背景放射の 観測結果は宇宙が平坦であ ることを示しており、左下か ら右上に伸びる紺色のバナナ 型の外側にある状態方程式の 定数と物質密度の值を除外す る。超新星の観測からは宇宙 の膨張の加速の程度がわか るが、これにより右下から左 上に伸びる薄い水色と濃い水
色のバナナ型の外側の值が除 外される。銀河団の測定は加 速を知るもう 1 つの方法であ り、薄い紫色と濃い紫色の領 域の外側の值が除外される。 すべての観測結果を統計的に 組み合わせると、緑色の小さ い丸型の領域が得られる。

どの観測法についても、 内側の線は68パーセントの 確からしさで除外される領 域との境界を、外側の線は 95 パーセントの確からしさ で除外される領域との境界 を示している。 


\section{進むべき道は ?}

状態方程式の定数を決めていくためには、 単一の観測法に頼るよりも、各種の観測 法を組み合わせるほうがよい(コラム「ダー クエネルギーを追い詰める」を参照)。新 しい研究法の中では、宇宙の大規模構造 がダークエネルギーによってどのように形 作られたり歪められたりしてきたかを調 ベる方法が最も有望視されている。銀河 は宇宙に均等に分布しているわけではな く、寄り集まって3次元のクモの巣構造を 作っている。このクモの巣はダークエネル ギーの影響を受けやすい。さらに、独自の 超新星観測チームを率いてPerlmutterら の観測チームと競争しているジョンズホプ キンズ大学の天文学者Adam Riessによ ると、大規模構造の観測で予想される誤 差の種類は、超新星の観測に伴う誤差の 種類とまったく異なっているため、この 新しい観測法は古い観測法とうまく補い 合うことになるという。現在、宇宙の大 規模構造の地図作りを進めるために、い くつかの野心的な調査が計画されている。

しかし、こうした方法のどれをとっても、 歯がゆいほど何も教えてくれない状態方 程式の定数を限定していくことしかできな い。ダークエネルギーが宇宙定数であるこ とを証明するには、状態方程式の定数が本 当にー1であることを示す必要がある。-1 に近いことを示すだけでは不十分なのだ。 ドイツのガルヒンクにあるマックスプランク 宇宙物理学研究所のSimon White所長は、 「天文学者たちは、ほかの仮説の可能性を 除外することもできないまま、いつまでも ダークエネルギーを測定し続けることにな るかもしれない。それが定数であるなら、 無限の正確さが必要となるからだ」と話す。

ケースウエスタンリザーブ大学（オハ イオ州クリーブランド）の理論物理学者 Lawrence Krauss はさらにこう指摘す る。状態方程式の定数が本当に-1であり、 ダークエネルギーが定数であるなら、膨張 の加速に及ぼす効果を通じてしかそれを 測定できないことになる。「状態方程式の 定数が-1であるなら、ダークエネルギー の正体は解明できないだろう。これでは まったく理論の指針にならないからだ」と Kraussは話す。
英国のダラム大学の理論物理学者 Carlos Frenkは、しっかりした理論的根 拠なしに1つの数字を調べるのは正しいや り方ではないと主張する。「それは、すべ ての木の高さを測定して、生物学の本質 を知ろうとするようなものだ」と彼はい う。「測定のための測定は無意味である」。 Frenkはそのような測定に多額の研究資金 を投じることに異議を唱えており、Loeb もこれに同意している。「この目的にも資 金は出さなければならないが、ほどほど の額にするべきだ」とLoebは話す。

一部の理論物理学者の懸念とは裏腹に、 実際に観測を行っている天文学者たちは、 状態方程式の定数の測定を続けることが 最も賢明な道だと考えている。なんといっ ても、現在できるのはこの観測だけである からだ。Bennettは、「測定は限界まで行 うべきだ」と主張する。「驚くべき事実が 明らかになるかもしれないし、そうしたこ とはしばしば起こる」。 Perlmutterも、研 究を御破算にするためではなく、収拾する ために、いくつか結果を出す余地があると 考えている。「『私たちは十分やった』とあ きらめるにしても、いくつか退屈な結果を 得てからにしたいというようなものだ」と 彼は話す。

Bennett と Perlmutter はさらなる観測 に意欲を燃やしており、Bennettは人工衛 星を使って銀河の構造を観測する計画を、 Perlmutter は遠方の超新星を観測する計 画を提案して、米航空宇宙局 (NASA) と 米国エネルギー省 (DOE)がダークエネルギー 観測衛星のために検討している予算を獲得 しようと争っている。これによりダークエ ネルギーをめぐる議論をいくらか正確にす る程度の知見しか得られなかったとしても、 宇宙について多くのことが明らかになるは ずである。例えば、宇宙から超新星を観測 する衛星があれば、全天の赤外線天体につ き正確な観測結果が得られるだろう。ス夕 ンフォード大学カブリ粒子宇宙物理学・宇 宙論研究所（カリフォル二ア州）のRoger Blandford所長は、「こうした装置は特定の 目的にしか使えないものではない」という。 「あらゆる分野に革命を起こし得るのだ」。 ダークエネルギーの解明につながる待望 の新しい手がかりがほかの研究分野から
得られる可能性は常にある。2008年に なって、スイスのジュネーブ近郊にある欧 州原子核共同研究機関 (CERN) のラージ ハドロンコライダー (ハドロン衝突型大加 速器）がデー夕を取り始めたら、時空の本 質に関する発見があるかもしれない。こ れはダークエネルギー問題にもかかわって くる。「ひょっとすると、宇宙よりも加速 器のほうが、多くのことを教えてくれる かもしれない」とKraussは話す。同様に、 基本定数の測定や短距離での重力の測定 が、ダークエネルギー問題と予想外の関係 をもっている可能性がある。さらに、ある 種のダークマター粒子の検出もダークエネ ルギー問題の解決に役立つかもしれない。

10 年前にダークエネルギーの証拠が発 見されたときに期待された革命は、いま だに実現していない。研究者たちは宇宙 の膨張が加速していることへの確信を深 めたものの、その物理的な意味について は1998年当時と同じぐらいわかってい ない。「今は2つの可能性がある。ダーク エネルギーが真空のエネルギーである可 能性と、ほかの何かである可能性だ」と Carroll は話す。観測を行っている天文学 者たちはもう少し楽観的だ。「この研究 は始まったばかりの段階にあるのだと私 は思う」とPerlmutterはいう。とはい え、状態方程式の定数が-1から外れる結 果が得られなかった場合、何かが明らか になる可能性は低いだろうということは Perlmutterも認めている。「獲物の気配が なかったら、狩りをするのはむずかしい」。

今、この分野の多くの研究者が不安を 感じている。彼らはかつて、あと少しです ばらしい手がかりが得られると思っていた が、探求の過程で、いつしか腹立たしい謎 に変わってしまった。Susskindは、「宇宙 の4分の3を占めている可能性のあるもの について明確な説明ができないという状 況で、自分たちの宇宙像には大きな欠落 があると考えずにいることはむずかしい。 私たちの宇宙像は、今後 1000 年にわたっ て間違ったままであるのかもしれない。大 きく間違ったままに…と話した。

Geoff Brumfiel は Nature のワシントン DC 物 理科学担当記者。 